\title{
GUIDANCE AND COUNSELING TEACHER TENURE OF APPLICATIONS INSTRUMENTATION AT SMP OF METRO CITY
}

\author{
SITI SUNDARI \& SATRIO B.W
}

Program Studi Bimbingan dan Konseling UM Metro

\begin{abstract}
Activity instrumentation applications is supporting activities that strongly supports the achievement of the effectiveness of counseling services organized by BK teacher. Goals to be achieved by the researchers is to determine how the level of mastery of instrumentation applications teacher guidance and counseling junior at Metro City. The quantitative Descriptive research design used. The results showed mastery of instrumentation applications BK junior high school teacher in the city of Metro is quite good, with the percentage of $64.81 \%$. In all four aspects studied lowest percentages are aspects of the execution and reporting that is $15.46 \%$, and which has the highest percentage is the aspect of evaluation ie $17.13 \%$. Suggestions put forward, namely upgrading of instrumentation in guidance and counseling teacher training and seminars on instrumentation activities.
\end{abstract}

Keyword: Instrumentation Applications, Master of Guidance and Counseling

\section{PENDAHULUAN}

Proses pendidikan yang dilakukan pada satuan-satuan pendidikan tidak terlepas dari berbagai permasalahan dan hambatan-hambatan. Hambatan dan permasalahan yang muncul dapat berasal dari berbagai hal, seperti sumber daya manusianya (peserta didik, pendidik, dan juga tenaga kependidikan), sarana prasarana, dukungan masyarakat,kurikulum, regulasi tentang pendidikan, dan lainlain. Setiap permasalahan yang muncul memerlukan penanganan dan solusi yang berbeda antara satu masalah dengan masalah lain.

Sebagai salah satu komponen pendidikan, peserta didik kerap mengalami kendala dalam proses pendidikan yang sedang dijalaninya. Hasil belajar yang rendah,motivasi belajar menurun, masalah dengan hubungan teman sebaya, dan masih banyak lagi masalah yang dialami oleh peserta didik. Menurut Prayitno dan Erman Amti (2004) masalah yaitu: 1) suatu hal yang tidak disukai keberadaannya, 2) sesuatu yang ingin 
dihilangkan keberadaannya, dan 3) sesuatu yang dapat menimbulkan kerugian dan/atau kesulitan baik untuk sekarang maupun akan datang. Bentuk masalah yang dialami oleh siswa sangatlah beragam dan berbeda pada setiap siswa. Masalah yang dihadapi oleh siswa dapat berupa masalah umum dan masalah belajar. Prayitno (1997) menyebutkan masalah umum meliputi.

1) Masalah jasmani dan kesehatan (JDK),

2) Masalah diri pribadi (DPI),

3) Masalah hubungan sosial (HSO),

4) Masalah ekonomi dan keuangan (EDK),

5) Masalah karir dan pekerjaan (KDP),

6) Masalah pendidikan dan pelajaran (PDP),

7) Masalah hubungan muda-mudi (HMM),

8) Masalah keadaan hubungan keluarga (KHK),

9) Masalah agama, nilai dan moral (ANM),

10) Masalah waktu senggang (WSG).

Masalah-masalah tersebut di atas terkait dengan permasalahan yang terjadi dalam kehidupan keseharian siswa, sedangkan masalah yang khusus terkait dengan kondisi belaajr siswa. Prayitno (1997) merinci sebagai berikut:

a. Prasyarat penguasaan materi pelajaran $(\mathrm{P})$,

b. Keterampilan belajar (T), c. Sarana belajar (S),

d. Keadaan diri pribadi (D) dan

e. Lingkungan belajar dan sosioemosional (L).

Berbagai masalah yang dialami oleh peserta didik harus ditangani secara profesional, dan dilakukan oleh personel yang memiliki kualifikasi dan kompetensi yang sesuai, yaitu guru Bimbingan dan Konseling. Hal tersebut sesuai dengan penjelasan Prayitno (2010: 29) yang menjelaskan bahwa objek praktis konselor adalah mengembangkan kehidupan efektif sehari-hari (KES), dan menangani kehidupan efektif sehari-hari yang terganggu (KES -T) peserta didik.

Lebih lanjut, dijelaskan dalam PP No.74 tahun 2008, Guru BK adalah petugas konseling pada satuan-satuan pendidikan yang telah menempuh pendidikan S1 BK. Beban kerja guru BK mengampu paling sedikit 150 (seratus lima puluh) peserta didik dan paling banyak 250 (dua ratus lima puluh) peserta didik pertahun pada satu atau lebih satuan pendidikan yang dilaksanakan dalam bentuk layanan tatap muka terjadwal di kelas untuk layanan klasikal dan/atau di luar kelas untuk layanan perorangan atau kelompok bagi yang dianggap perlu dan yang memerlukan. Mengingat 
beban yang sangat besar dengan jumlah siswa asuh yang cukup banyak, maka variasi permasalahan yang dialami juga cukup tinggi dan komplek. Oleh karena itu, untuk memperoleh informasi yang tepat akan kebutuhan dan masalah siswa, guru BK hendaknya melakukan kegiatan instrumentasi.

Pelaksanaan layanan bimbingan dan konseling di sekolah tidak dapat berjalan secara efektif apabila tidak didukung dengan kegiatan pendukung. Prayitno (2004) menyebutkan bahwa kegiatan pendukung bimbingan meliputi lima kegiatan pokok, yaitu: aplikasi instrumentasi, penyelenggaraan himpunan data, konferensi kasus, kunjungan rumah, dan alih tangan kasus. Semua jenis kegiatan pendukung itu dilaksanakan di sekolah dan secara langsung dikaitkan dengan ketujuh bidang bimbingan (pribadi, sosial, belajar, karir, keluarga, beragama, dan kewarganegaraan), serta disesuaikan dengan karakteristik dan kebutuhan siswa.

Kegiatan pendukung yang dapat digunakan sebagai dasar dalam menentukan jenis layanan, serta materi layanan dalam pelaksanaan pelayanan konseling adalah kegiatan aplikasi instrumentasi. Menurut Prayitno dan
Amti (2004) Aplikasi instrumentasi merupakan kegiatan pendukung layanan bimbingan dan konseling untuk mengumpulkan data dan keterangan tentang klien, keterangan tentang lingkungan yang lebih luas, pengumpulan data ini dapat dilakukan dengan berbagai instrumen baik dengan tes maupun non tes. Melalui kegiatan aplikasi instrumentasi, guru BK dapat secara benar memahami kebutuhan dan masalah siswa. Hal itu sesuai dengan pendapat Tohirin (2013) tujuan aplikasi instrumentasi adalah:

a. Secara umum, tujuan aplikasi instrumentasi adalah supaya diperolehnya data tentang kondisi tertentu atas diri klien (siswa).

b. Secara khusus, apabila dikaitkan dengan fungsifungsi bimbingan dan konseling terutama fungsi pemahaman, data hasil aplikasi instrumentasi bertujuan untuk memahami kondisi klien (siswa) seperti potensi dasarnya, bakat dan minatnya, kondisi diri dan lingkungannya, masalahmasalah yang dialami dan lain sebagainya.

Melalui aplikasi instrumentasi dapat dijadikan dasar untuk pemberian bantuan atau layanan kepada siswa sesuai dengan kebutuhan. Penerapan aplikasi instrumentasi di sekolah yang 
efektif dalam mengumpulkan selengkap mungkin data siswa ialah dengan menggunakan teknik tes dan non tes. Melalui teknik tes maupun non tes, maka guru BK dapat memperoleh pemahaman tentang siswa secara lebih konkrit serta relevan.

Sebagai salah satu kegiatan pendukung, kegiatan aplikasi insrumentasi pada dasarnya merupakan salah satu indikator dari kompetensi profesional guru BK. Menurut Sudrajat (http:// Aspek dan Indikator Kompetensi Profesional Guru Bimbingan dan Konseling. Diakses pada tanggal 13/05/2013) kompetensi yang harus dikuasai seorang guru bimbingan dan konseling atau konselor dalam menerapkan aplikasi instrumentasi, yaitu: "Menguasai konsep dan praksis penilaian (assessment) untuk memahami kondisi, kebutuhan, dan masalah konseli." Dengan demikian sangat mutlak dan menjadi keharusan bagi guru BK mampu menguasai berbagai instrumen pengumpul data, mampu mengaplikasikan, mengolah hasil instrumentasi, serta melakukan tindak lanjut terhadap hasil kegiatan aplikasi instrumentasi.
Berdasarkan hasil pra survey pada tanggal 12 sampai 17 oktober 2013 yang peneliti lakukan di 5 (lima) Sekolah Menengah Pertama (SMP), yaitu: SMP Negeri 2 Metro, SMP Negeri 3 Metro, SMP Negeri 5 Metro, SMP Negeri 6 Metro, dan SMP Negeri 9 Metro diketahui beberapa permasalahan yang ada tentang aplikasi instrumentasi di sekolah tersebut, seperti masih kurangnya kemampuan guru BK dalam melakukan kegiatan aplikasi instrumentasi, kegiatan aplikasi sudah dilakukan, namun dalam tindak lanjut masih guru BK sering mengalami kendala-kendala, guru BK masih mengalami kebingungan untuk melakukan pengolahan instrumentasi secara komputerisasi.

Pada hasil pra survey di atas, diketahui bahwa dalam layanan pendukung aplikasi instrumentasi di 5 (lima) SMP Negeri di kota Metro masih perlu dilakukan peningkatan karena masih mengalami banyak kendala.. Sehubungan dengan hal tersebut, asumsi peneliti tentang kurangnya tingkat penguasaaan aplikasi instrumentasi disebabkan oleh beberapa faktor, yaitu: kurangnya pengalaman dan pelatihan menggunakan aplikasi instrumentasi, 
latar belakang pendidikan dari non bimbingan dan konseling, dan kurangnya kemampuan guru bimbingan dan konseling dalam menggunakan teknologi informasi dan komunikasi (TIK).

Dalam penelitian ini peneliti merumuskan masalah sebagai berikut: "Bagaimana Tingkat Penguasaan Aplikasi Instrumentasi Guru Bimbingan dan Konseling SMP di Kota Metro ?". Tujuan yang hendak dicapai dari penelitian ini adalah adalah mendeskripsikan tingkat penguasaan aplikasi instrumentasi guru bimbingan dan konseling SMP di Kota Metro. Melalui penelitian ini diharapkan memberikan manfaat bagi guru BK dan pengembangan kelimuan Bimbingan dan Konseling, yaitu sebagai bahan informasi ilmiah untuk menambah referensi dan pengetahuan dalam bidang bimbingan dan konseling, khususnya tentang pelaksanaan aplikasi instrumentasi, , dan bagi guru BK Dapat menambah ilmu pengetahuan dan wawasan tentang penerapan aplikasi instrumentasi kepada siswa secara tepat yang sesuai dengan kebutuhan siswa tersebut, sehingga dalam pengumpulan data siswa menjadi konkrit serta relevan.

\section{METODE PENELITIAN}

Jenis penelitian yang digunakan yaitu menggunakan metode penelitian deskriftif kuantitatif. Menurut Sukmadinata (2012: 74) menyatakan bahwa: "Penelitian deskriptif adalah suatu bentuk penelitian yang paling dasar, karena peneliti tidak melakukan manipulasi atau memberikan perlakuan-perlakuan tertentu terhadap variabel atau merancang sesuatu yang diharapkan terjadi pada variabel, tetapi semua kegiatan, keadaan, kejadian, aspek, komponen atau variabel berjalan sebagaimana adanya. Populasi dalam penelitian ini meliputi seluruh guru bimbingan dan konseling SMP di Kota Metro yang berjumlah 80 guru. Penetuan sampel dengan menggunakan teknik Proportional Random Sampling, dan rumus yang digunakan untuk menentukan jumlah sampel yaitu rumus Slovin (Ridwan, 2005) Jumlah sampel dalam penelitian ini berjumlah 27 guru bimbingan dan konseling. Teknik pengumpulan data yaitu menggunakan teknik tes, dan data yang diperoleh dianalisis dengan menggunakan rumus

rumus persentase, yaitu:

$$
P=n: N \times 100 \%
$$


Keterangan :

$$
\begin{array}{ll}
\mathrm{P} & =\text { Persentase } \\
\mathrm{n} & =\text { Skor nyata } \\
\mathrm{N} & =\text { Skor Ideal }
\end{array}
$$

\section{HASIL DAN PEMBAHASAN}

Pada pelaksanaan penelitian ini, peneliti memberikan tes tingkat penguasaan aplikasi instrumentasi kepada guru bimbingan dan konseling SMP di Kota Metro. Berdasarkan hasil tes tersebut, penguasaan aplikasi instrumentasi yang dimiliki oleh guru bimbingan dan konseling memiliki persentase $64,81 \%$. Hasil persentase tersebut dapat diinterpretasikan bahwa guru bimbingan dan konseling di SMP se-Kota Metro pada tingkat penguasaan aplikasi instrumentasi baik. Temuan penelitian memberikan informasi bahwa secara umum guru BK SMP sekota Metro telah mampu melakukan kegiatan aplikasi instrumentasi. Dengan demikian, dapat dimaknai bahwa pelayanan konseling yang dilakukan oleh guru BK setidaktidaknya mengacu kepada analisis kebutuhan dan masalah siswa.

Siswa SMP berada pada usia yang sangat labil. Kondisi psikologis siswa seusia anak SMP cenderung berubah. Kondisi tersebut memerlukan pemahaman dan analisis yang tepat oleh guru BK. Mengacu kepada hasil penelitian, penguasaan kegiatan aplikasi instrumentasi oleh guru BK SMP kota Metro berada pada kondisi cukup baik, oleh karena itu hendaknya dalam tindak lanjutnya guru BK harus memahami tanggung jawabnya. Prayitno, (2004) mengemukakan guru BK memiliki tanggung jawab kepada siswa terkait pengungkapan pengumpulan data, diantaranya yaitu:

a) kepada siswa yang harus diperlakukan sebagai individu yang unik

b) Memperhatikan sepenuhnya segenap kebutuhan siswa (kebutuhan yang menyangkut pendidikan, jabatan/pekerjaan, pribadi dan sosial) dan mendorong pertumbuhan dan perkembangan yang optimal bagi setiap siswa

c) Menjaga kerahasiaan data tentang siswa

d) Menyelenggarakan pengungkapan data secara tepat dan memberitahu siswa tentang hasil kegiatan secara sederhana

Hal tersebut sesuai dengan teori Berdie dalam Supriatna (2011) yang 
menyatakan bahwa "jika konselor ingin melakukan kegiatan bimbingan secara efektif atau melakukan kerja apa saja dengan siswa (klien), maka dia harus mengetahui segala sesuatu yang ada pada siswa (klien) nya tersebut." Kegiatan aplikasi instrumentasi sangat penting dilakukan oleh guru BK demi untuk memperoleh pemahaaman dan informasi yang tepat kondisi calon konselinya.

Aspek yang harus diperhatikan oleh guru BK, dan merupakan ciri khas keprofesionalan guru BK adalah mampu menjaga kerahasiaan data dari siswa setelah melakukan kegiatan aplikasi instrumentasi, terkecuali atas permintaan konseli. Hal ini perlu diperhatikan, karena guru BK harus membangun kepercayaan konseli terhadap guru BK dan kepercayaan terhadap pelayanan konseling.

Peneliti memberikan tes kepada guru bimbingan dan konseling untuk mengetahui seberapa tinggi tingkat penguasaan aplikasi instrumentasi. Guru bimbingan dan konseling di sekolah harus profesional dalam melaksanakan kegiatan pelayanan konseling, baik dari pemberian layanan serta melakukan kegiatan pendukung layanan. Sesuai dengan pendapat
Prayitno (2004: 6) yang menyatakan bahwa: "Guru bimbingan dan konseling adalah seorang ahli dalam bidang konseling, yang memiliki kewenangan dan mandat secara profesional untuk melaksanakan kegiatan pelayanan konseling." Hal yang harus dikuasai oleh seorang guru bimbingan dan konseling atau konselor ialah dengan melaksanakan aplikasi instrumentasi.

Peningkatan kemampuan guru BK dalam penguasaan kegiatan aplikasi instrumentasi harus dilakukan. Hal itu dikarenakan, pada beberapa aspek/indikator masih menunjukkan penguasaan yang rendah. Pada aspek pelaksanaaan dan laporan yaitu $15,46 \%$ berada pada kondisi yang masih rendah. Padahal aspek ini adalah inti dari kegiatan aplikasi instrumentasi. Banyak faktor yang mempengaruhi kemampuan guru BK menguasai kegiatan aplikasi instrumentasi. Menurut Kartini (2011: 37) menyatakan ada 8 faktor yang dapat mempengaruhi kompetensi profesional guru dalam penguasaan aplikasi instrumentasi yaitu:

a. Traning yang bisa juga dan disebut dengan pendidikan dan latihan (diklat) dan musyawarah guru mata pelajaran (MGMP) atau musyawarah guru bimbingan 
dan konseling (MGBK).

b. Kualifikasi akademik atau disebut dengan latar belakang pendiddikan.

c. Supervisi akademi atau disebut dengan pengawasan secara berkelanjutan.

d. Kepemimpinan kepala sekolah.

e. Motivasi.

f. Kesejahtraan atau kompetensi.

g. Etos kerja.

h. Kemampuan menggunakan teknologi informasi dan komunikasi (TIK).

Merujuk kepada teori di atas, maka upaya yang dilakukan untuk meningkatkan kualitas penguasaan kegiatan aplikasi instrumentasi harus didasarkan kepada jenis penyebab guru BK mengalami kendala melakukan kegiatan aplikasi instrumentasi, sehingga upaya yang dilakukan dapat berhasil secara efektif.

Memiliki penguasaan aplikasi instrumentasi yang baik dapat mengungkapkan kondisi siswa (klien) lebih efektif. Hal ini sesuai dengan tujuan aplikasi instrumentasi menurut Tohirin (2007: 208) yang menyatakan bahwa "tujuan aplikasi instrumentasi adalah supaya diperolehnya data tentang kondisi tertentu atas diri klien (siswa). Dengan data yang akurat, penyelenggaraan layanan bimbingan dan konseling disekolah akan lebih efektif dan efisien.
Berdasarkan penjabaran di atas, maka dapat disimpulkan bahwa guru bimbingan dan konseling yang memiliki kompetensi penguasaan aplikasi instrumentasi yang baik dapat menyelenggarakan layanan bimbingan dan konseling secara profesional, sehingga hasil yang dicapai menjadi efektif serta efisien.

\section{KESIMPULAN DAN SARAN}

\section{Kesimpulan}

Berdasarkan hasil analisis serta temuan penelitian, maka dapat disimpulkan bahwa tingkat penguasaan aplikasi instrumentasi guru SMP bimbingan dan konseling di Kota Metro dalam kategori baik. Simpulan tersebut ditunjukan dari temuan hasil analisis sebagai berikut:

1. Hasil tes tingkat penguasaan aplikasi instrumentasi dari 27 guru SMP bimbingan dan konseling di Kota Metro yang memiliki persentase terendah adalah aspek pelaksanaaan dan laporan yaitu $15,46 \%$, dan yang memiliki persentase tertinggi adalah aspek evaluasi yaitu $17,13 \%$. Pada seluruh aspek pengetahuan, pelaksanaan, evaluasi, dan laporan memiliki persentase $64,81 \%$, dengan 
demikian tingkat penguasaan aplikasi instrumentasi guru bimbingan dan konseling SMP di Kota Metro diinterpretasikan baik.

2. Guru bimbingan dan konseling yang terindikasi kurang pemahaman tentang aplikasi instrumentasi yaitu disebabkan oleh latar belakang pendidikan yang tidak sesuai, belum banyak pengalaman, dan kurangnya pelatihan(Training) khusus tentang pemanfaatan penggunaan aplikasi instrumentasi di sekolah, sehingga pelaksanaan aplikasi instrumentasi di sekolah belum berjalan secara kompeherensif (keseluruhan) serta optimal.

\section{Saran}

Berdasarkan hasil penelitian ini, maka peneliti memberikan beberapa saran antara lain sebagai berikut:

1. Agar menjadi guru bimbingan dan konseling yang berkompetensi serta profesional di sekolah yang perlu dilakukan adalah dengan sering mengikuti workshop dan pelatihanpelatihan khusus tentang bimbingan dan konseling agar pengalaman semakin bertambah, sehingga guru bimbingan dan konseling mempunyai kemampuan serta keahlian yang berkualitas untuk membantu menyelesaikan permasalahan siswa secara kompeherensif, efisien, dan efektif.

2. Aplikasi instrumentasi dalam pelaksanaannya harus dikuasai oleh guru bimbingan dan konseling, hal ini dikarenakan layanan bimbingan dan konseling di sekolah tidak akan dapat dilaksanakan secara efektif sesuai dengan tujuan yang direncanakan apabila kegiatan pendukung layanan tidak dilaksanakan secara profesional, sehingga penguasaan aplikasi instrumentasi sangat dibutuhkan untuk mencapai hasil layanan yang optimal.

3. Kepala sekolah harus mampu menyeleksi guru bimbingan dan konseling yang memiliki kompetensi yang profesional dalam penguasaan aplikasi instrumentasi, sehingga dapat memenuhi kebutuhan siswa (need assesment) secara tepat serta program layanan bimbingan dan konseling berjalan secara efektif. 
DAFTAR PUSTAKA

Felik, Efendy. 2012. Aplikasi

Instrumentasi dan Himpunan

Data.

(http://aplikasi instrumentasi

dan himpunan data.htm/

Wednesday, June 27, 2012

diakses pada tanggal 29 April

2013)

Prayitno. 2003. Buku III Pelayanan

Bimbingan dan Konseling. Jakarta: PT Bina Sumber Daya MIPA.

. 2004. Seri Layanan

Konseling L1-9. Padang:

Universitas Negeri Padang

, 2010. Seri Modul Pendidikan

Profesi Guru. Padang: FIP Jurusan BK. UNP

, 1997.Pedoman Alat Ungkap

Masalah (AUM) PTSDL

format-2 SLTA. Padang FIP

IKIP Padang.

Prayitno dan Amti. 2004. Dasar-Dasar Bimbingan dan Konseling. Jakarta: PT Rineka Cipta

Purwoko, Budi. 2007. Pemahaman Individu Melalui Teknik Non

Tes. Surabaya: Unesa Universiti Pres.

Ridwan. 2005. Metode dan Teknik Menyusun Tesis. Bandung: Alfabeta.

Sudrajat, Akhmad. 2012. Aspek dan Indikator Kompetensi
Profesional Guru Bimbingan dan Konseling.

Blogspot.(online).

(http:// Aspek dan Indikator

Kompetensi Profesional Guru

Bimbingan dan Konseling _ tentang PENDIDIKAN.htm diakses pada tanggal 13 mei 2013)

Sukardi, Dewa Ketut. 2008. Proses Bimbingan dan Konseling di Sekolah. Jakarta: Rineka Cipta.

Sukmadinata, Nana Syaodih. 2012. Metode Penelitian Pendidikan. Bandung: PT Remaja Rosdakarya.

Supriyatna, Mamat. 2011. Bimbingan dan Konseling Berbasis Kompetensi. Jakarta: PT. Raja Grafindo Persada.

Tohirin. 2009. Bimbingan dan Konseling di Sekolah dan Madrasah. Pekanbaru: PT. Raja Grafindo.

2013. Bimbingan dan

Konseling di Sekolah dan

Madrasah (Berbasis

Integrasi). Jakarta: Rajawali

Pers.

Triyanto, Agus. 2011. Memahami individu dengan teknik non tes (observasi dan wawancara). (online)

(http://memahami-individudengan-teknik-non-tes.pdf. diakses pada tanggal 29/04/2013) 